\title{
Significance of bio-treatment by acid washing for enlargement of arsenic desorption in indigenous arsenic-resistant bacteria from gold mine
}

\author{
Wahid Ali Hamood Altowayti a, ", Abdullah Aysh Dahawi ${ }^{\text {b }}$, Shafinaz Shahir c, ${ }^{*}$ \\ ${ }^{a, c}$ Department of Bioscience, Faculty of Science, Universiti Teknologi Malaysia, 81310 UTM Johor Bahru, Johor, Malaysia \\ b Department of Mathematics, Faculty of Science, Universiti Teknologi Malaysia, 81310 UTM Johor Bahru, Johor, Malaysia \\ * Corresponding authors: ahawahid2@live.utm.my, shafinazshahir@utm.my
}

\section{Article history}

Received 9 February 2019

Revised 1 August 2019

Accepted 18 September 2019

Published Online 15 April 2020

Graphical abstract

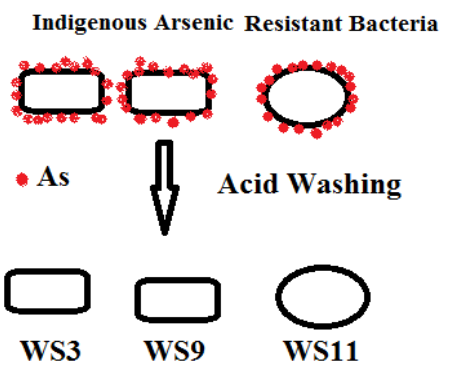

\begin{abstract}
Mining activities can lead to the generation of large quantities of heavy metal, specifically arsenic which is released from a gold mine, causing widespread contamination of the ecosystem. Removal of carcinogenic and toxic arsenic from wastewater is essential for the safety of water that may be used for irrigation or drinking. In this study, three different of indigenous arsenic resistant bacterial strains were isolated from gold mine environment, Bacillus thuringiensis strain WS3, Pseudomonas stutzeri strain WS9, and Micrococcus yunnanensis strain WS11. WS9, WS3, and WS11 reached stationary phase after eight, ten, and seven hours, respectively, at $37^{\circ} \mathrm{C}$ when grown in LB with arsenic. Gram staining showed WS9 as gram-negative rods, WS3 as grampositive rods, and WS11 as gram-positive cocci. From the Silver nitrate test, WS3 and WS11 reduced As (V) to As (III) while WS9 oxidized As (III) to As (V). The desorption of arsenic using acid washing and parameters affecting the desorption of arsenic such as acid concentration, time, adsorbent dosage, and different volume of acid solution were investigated. The batch experiments were carried out using bacterial biomass cultured in LB with $2 \mathrm{mM}$ arsenite (III) and $5 \mathrm{mM}$ arsenate (V). Optimum conditions for desorption arsenic were determined, being $1 \mathrm{M}$ acid concentration at $37^{\circ} \mathrm{C}$ and 2 hours of contact with $(50 \mathrm{mg})$ bacterial biomass in $100 \mathrm{ml}$ acid solution. The removal of arsenite and arsenate increased after acid washing of bacterial biomass of the three strains. Consequently, desorption of arsenic using acid washing is essential for biomass regeneration.
\end{abstract}

Keywords: Acid washing, desorption, arsenic, biomass, bio-treatment, goldmine.

(C) 2020 Penerbit UTM Press. All rights reserved

\section{INTRODUCTION}

Arsenic (As) has an atomic number of 33 and it comprises around $0.0005 \%$ of the crust of the earth. It has an atomic weight of (74.9216) and it melts at $817^{\circ} \mathrm{C}$ and boils at $613{ }^{\circ} \mathrm{C}$ at $28 \mathrm{~atm}$. Furthermore, it has a silver-grey brittle crystalline colour and vapours at $372{ }^{\circ} \mathrm{C}$ in pressure of $1 \mathrm{~mm} \mathrm{Hg}$ with a specific gravity of 5.73. It also exists in the oxidation states $(+5,+3,0,-3)$ (Wu et al., 2010). Arsenic can be found in the environment as arsenious acids $\left(\mathrm{H}_{3} \mathrm{AsO}_{3}{ }^{2+}, \mathrm{H}_{3} \mathrm{AsO}_{4}\right.$, $\mathrm{H}_{3} \mathrm{AsO}_{3}$ ). Moreover, As (V) is like a soft acid and can form a complex with sulfides. On the other hand, As (III) is a firm acid which forms a compound with nitrogen and oxides (Mohan and Pittman, 2007). More than 100 million people universally, mainly in Bangladesh, India, China, Taiwan, Thailand, Chili, and Romania are exposed to dangerous levels of arsenic (Singh et al., 2007). Therefore, the removal of heavy metals such as arsenic from wastewater and water are important to protect a public health (Zaini et al., 2011).

Microbes have co-habit with different metals from initial history. Thus, microorganisms have been effectively used to remove heavy metal such as Arsenic from wastewater in a variety of patterns. Consequently, from a functional concept, metals can be divided into three groups: (i) non-toxic and essential such as $\mathrm{Mg}$ and $\mathrm{Ca}$, (ii) harmful at high concentrations and essential in low concentration such as $\mathrm{Zn}, \mathrm{Mo}, \mathrm{Cu}, \mathrm{Ni}, \mathrm{Co}, \mathrm{Fe}$, and $\mathrm{Mn}$, and (iii) toxic even in low concentration such as $\mathrm{Cd}, \mathrm{Hg}$, and As. In addition, interaction with metals relies on the specific metal and its chemical speciation (Valls and De Lorenzo, 2002). Bio-treatment has received great attention in the recent years due to its low cost and high capacities. The purpose of this study was to propose a suitable conventional pre-treatment technology of indigenous arsenic resistant bacterial biomass to increase arsenic removal efficiency from wastewater.

To the best of our knowledge, there are no reports to date on optimising the pre-treatment of the biomass of indigenous arsenicresistant bacteria used for the bioremediation of As (III) and As (V). Therefore, in the present study, we focused on characterising arsenicresistant bacteria isolated from laden tailing dam sludge in goldmine and enhancing their ability to remove arsenic from aqueous solution through acid treatment. In addition, the desorption of As (III) and As (V) from the biomass of indigenous arsenic-resistant bacteria was studied and optimised at different acid concentrations, contact time, bacterial biomass dosage ( $\mathrm{mg}$ ), and hydrochloric acid solution volume $(\mathrm{mL})$.

\section{EXPERIMENTAL}

\section{Culture medium}

Luria Bertani (LB) was made by mixing $(5 \mathrm{~g})$ yeast extract, $(10 \mathrm{~g})$ sodium chloride, and $(10 \mathrm{~g})$ Tryptone in $(950 \mathrm{ml}) \mathrm{dH}_{2} \mathrm{O}$ with the $\mathrm{pH}$ adjusted to $\mathrm{pH} 7.0$ and the volume continued to 1 litre. After that, the mixture was autoclaved for $20 \mathrm{~min}$ at $121{ }^{\circ} \mathrm{C}$. For solid LB, 1.5\% agar powder was added to the LB broth before autoclaving.

\section{Analysis of arsenite}

The modified molybdenum blue method was used to measure the concentration of As (III) and As (V) in the solutions (Cummings et al., 1999). The remaining arsenic in the solution was calculated from the slope of the standard curve. The standard curve for arsenite (III) and arsenate $(\mathrm{V})$ was made by plotting absorbance at $865 \mathrm{~nm}$ against 
the concentrations of As (III) and As (1-10 ppm) (Altowayti, Algaifi, et al., 2019).

\section{Bacterial strains}

Bacillus thuringiensis strain WS3, Pseudomonas stutzeri strain WS9, and Micrococcus yunnanensis strain WS11 were isolated from gold mine environment and submitted to the NCBI gene bank under accession numbers (MF099871), (MF106176), and (MF107934), respectively.

\section{Growth profile of arsenic-resistant bacteria (WS3, WS9, and WS11.}

Growth profiles of WS3 and WS9 were determined in LB medium containing $2 \mathrm{mM}$ arsenite whilst that for WS11 in LB containing 5 $\mathrm{mM}$. Isolates $(10 \mathrm{v} / \mathrm{v})$ were cultured in the respective media at $37^{\circ} \mathrm{C}$ with shaking at $150 \mathrm{rpm}$ for $15 \mathrm{hr}$. The growth of the bacteria was measured spectrophotometrically at $\mathrm{OD}_{600} \mathrm{~nm}$ at hourly intervals. LB broth without inoculum was used as a control.

\section{Gram staining and cell morphology}

Gram staining was observed under a light microscope. Grampositive bacteria were stained purple whereas Gram-negative bacteria were stained pink.

\section{Silver nitrate test}

The isolated bacteria (WS3, WS9, and WS1) were cultured on 0.1 Trypticase Soy Agar incorporated with $1 \mathrm{mM}$ As (III) or As (V) for 24 hours at $37^{\circ} \mathrm{C}$. Then, the agar plates were flooded with $0.1 \mathrm{M}$ $\mathrm{AgNO}_{3}$. Brownish precipitates revealed the presence of arsenate (silver orthoarsenate) in the medium while yellow precipitates (silver orthoarsenite) revealed the presence of arsenite in the medium (Simeonova et al., 2004).

\section{Preparation of bacterial biomass of WS3, WS9 and WS11}

Isolates WS3 and WS9 were grown in LB medium with $2 \mathrm{mM}$ As (III) and WS11 was grown in LB medium with $5 \mathrm{mM}$ As (V) until the maximum growth was reached. Then, the biomass was centrifuged at $10000 \mathrm{rpm}$ for $15 \mathrm{~min}$ and washed two times with ultra-pure water. Afterward, the biomass was dried out for $15 \mathrm{~h}$ at $70^{\circ} \mathrm{C}$ and crushed to small units using a mortar and pestle.

\section{Desorption of arsenic \\ 1) Effect of hydrochloric acid concentration}

Hydrochloric acid has been confirmed to be efficient for desorption of arsenic and regenerated biomass. The experiments were carried out at different concentrations of acid solution $(0.2,0.4,0.6$, $0.8,1,1.2$, and $1.4 \mathrm{M}$ ) to determine the optimum acid concentration for biomass washing. $100 \mathrm{ml}$ of the acid solution was added to $100 \mathrm{mg}$ of each strain in the $100 \mathrm{ml}$ conical flask. The solution was then mixed at $37^{\circ} \mathrm{C}$ for $5 \mathrm{~h}$. Then, the biomass in the acid solution was separated by centrifuging at $10,000 \mathrm{rpm}$ at $4{ }^{\circ} \mathrm{C}$ for $15 \mathrm{~min}$ before the extracted arsenic was analyzed.

\section{2) Effect of contact time}

To study the influence of contact time on desorption of arsenic from bacterial biomass, every $100 \mathrm{mg}$ of biomass was mixed with 100 $\mathrm{mL}$ acid solution at an optimum concentration in $100 \mathrm{~mL}$ conical flask for different washing durations $(1,1.5,2,2.5,3$ hours). The acid solution and the bacterial biomass were separated by centrifugation at $10,000 \mathrm{rpm}$ for $15 \mathrm{~min}$ at $4{ }^{\circ} \mathrm{C}$ and the arsenic removed was examined.

\section{3) Effect of bacterial biomass dosage ( $\mathrm{mg}$ )}

The dosage of bacterial biomass $(\mathrm{mg})$ is an essential factor in biomass washing. The optimum hydrochloric concentration and time were fixed. The dosage of 20,30, 40, 50, 60, and $70 \mathrm{mg}$ biomass for each strain WS3, WS9, and WS11 were added separately to $100 \mathrm{ml}$ acid solution at optimum mixing time. Then, the acid solution and the bacterial biomass were separated by centrifuging at $10000 \mathrm{rpm}$ for 15 min at $4{ }^{\circ} \mathrm{C}$ and the arsenic desorbed was calculated.

\section{4) Effect of volume $(\mathrm{mL})$ of hydrochloric acid solution}

The volume $(\mathrm{ml})$ of the acid solution is a significant element in biomass washing. In this experiment, the optimum parameters of hydrochloric acid concentration and time specified in previous tests were fixed to optimum biomass dosage. Based on $50 \mathrm{mg}$ of biomass, the volumes of $25,50,75,100,125$, and $150 \mathrm{ml}$ of acid solution were applied. Then, the acid solution and the bacterial biomass were separated by centrifugation at $10000 \mathrm{rpm}$ for $15 \mathrm{~min}$ at $4{ }^{\circ} \mathrm{C}$ and the arsenic in the solution was measured.

\section{Adsorption of arsenic}

The biomass $(50 \mathrm{mg})$ for the three strains WS3, WS9, and WS11 was separately subjected to acid washing using $100 \mathrm{ml}$ of $1 \mathrm{M} \mathrm{HCl}$ for 2 hours then centrifuged at $10000 \mathrm{rpm}$ at $4{ }^{\circ} \mathrm{C}$ for $15 \mathrm{~min}$ and washed twice with ultra-pure water to remove excess acid. Finally, the washed biomass was dried at $70{ }^{\circ} \mathrm{C}$ for $15 \mathrm{hr}$ and used for adsorption of As (III) and As (V) (Bahari et al., 2013). The biomass (5 mg) for WS3, WS9, and WS11 was separately mixed with As (III) and As (V) (8 ppm) in $100 \mathrm{ml}$ conical flask containing $10 \mathrm{ml}$ of the arsenic solution before and after acid washing. All tests were done in triplicate. The biomass was removed from the mixture by centrifugation for $15 \mathrm{~min}$ at $10000 \mathrm{rpm}$ and $4{ }^{\circ} \mathrm{C}$. The Arsenic remaining in the solution was examined.

\section{RESULTS AND DISCUSSION}

\section{Growth profile}

It is very important to know the growth profile of bacteria to get the maximum biomass of the cell which can be achieved in the late exponential phase to carry out the next experiment. The growth profiles of WS3, WS9, and WS11 as presented in Fig. 1 were obtained by monitoring changes in optical density $\left(\mathrm{OD}_{600}\right)$ for $12 \mathrm{~h}$ at $37^{\circ} \mathrm{C}$. From Fig. 1, the maximum growth for both WS3 and WS11 were after $10 \mathrm{~h}$ and $7 \mathrm{~h}$ and it was $8 \mathrm{~h}$ for WS9 in the LB medium with the highest $\mathrm{OD}_{600}$ measured which were (2.429), (2.493), and (2.198), respectively. Nonetheless, the growth profiles confirmed these strains have the ability to be cultivated in the lab using LB medium with arsenite or arsenate since these bacteria were previously isolated from an arsenic contaminated environment. Bacteria that can tolerate high concentrations of arsenic species are widespread in environment and have been successfully isolated (Anderson and Cook, 2004; Escalante et al., 2009; Pepi et al., 2007; Suresh et al., 2004). It has been reported that bacteria capable of resisting toxic heavy metals such as arsenic possess a protein known as DPS (DNA protection during starvation) which allows them to tolerate stressful conditions such as high concentrations of heavy metals (Chiancone and Ceci, 2010; Martinez and Kolter, 1997).

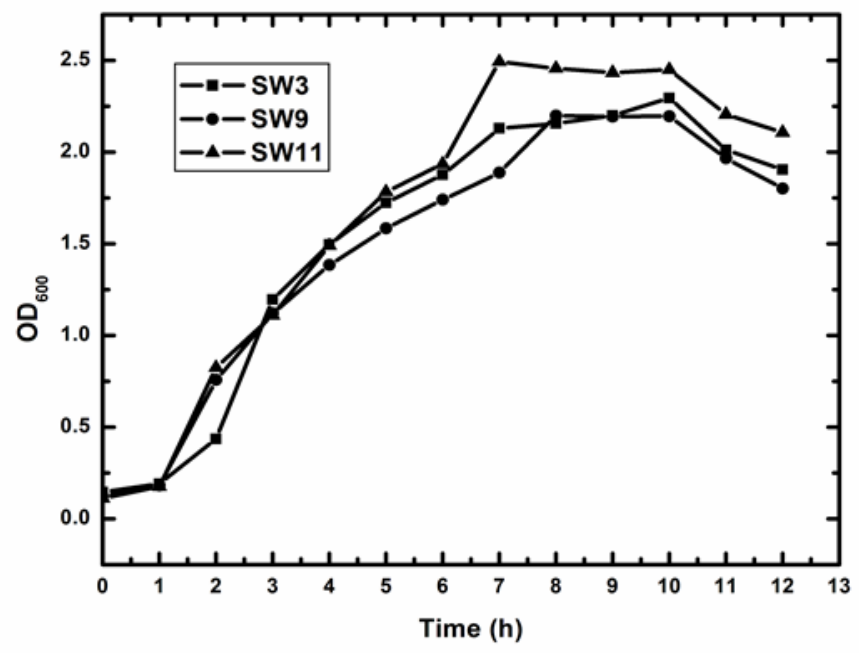

Fig. 1 Growth Profile of Arsenic-Resistant Bacteria (WS3, WS9, WS11)

\section{Gram staining}

Gram staining is used to distinguish between bacteria according to different constituents of their cell wall. The Gram stain procedure 
differentiates between Gram-negative and Gram-positive groups by colouring these cells pink or violet. Consequently, WS3 and WS11 were found to be gram-positive (thick layer of peptidoglycan, $90 \%$ of the cell wall), rod and cocci shape, respectively. Whilst, WS9 gramnegative (thin layer of peptidoglycan, $10 \%$ of the cell wall; high lipid content), rod-shape bacteria as shown in Fig. 2.

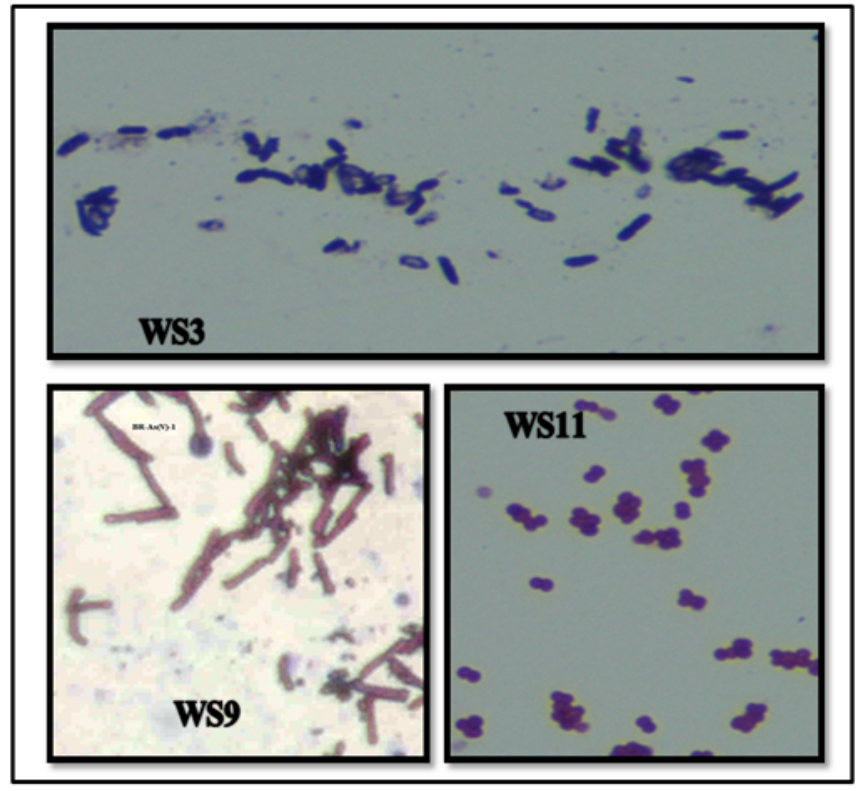

Fig. 2 Gram staining and Cell Morphology at 100x magnifications WS3 and WS11: Gram-positive. WS9: Gram-negative.

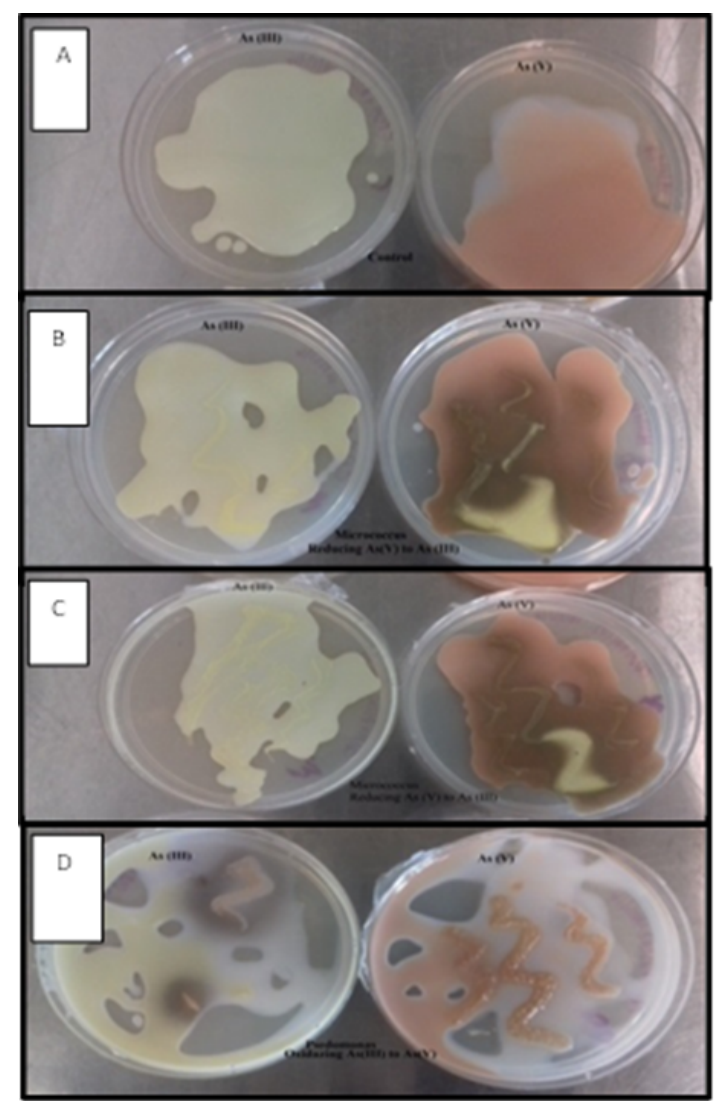

Fig. 3 A: control, B: WS3: Reducing bacteria, C: WS11: Reducing bacteria, D: WS9: Oxidising bacteria.

\section{Silver nitrate test}

All strains were grown on $0.1 \times$ TSA incorporated with $1 \mathrm{mM} \mathrm{As}$ (III) or As (V) for 2 days before the plates were flooded with $0.1 \mathrm{M}$
AgNO3 solution. From Fig. 3, WS3 and WS11 are As-reducing bacteria due to the formation of yellow precipitates which indicate the presence of As (III), while WS9 is As-oxidizing bacteria because the brownish precipitates show the presence of As (V). Therefore, it was concluded that the isolates WS3 and WS11 are capable of producing arsenate reductase enzymes (cytoplasmic arsenate reductase and a membrane-bound or periplasmic respiratory arsenate reductase) while WS9 have the ability to produce arsenite oxidase enzyme (periplasmic arsenite oxidase). Many arsenate-reducing bacteria (or arsenate reducers) capable of reducing As (V) to As (III) have also been identified and classified as Wolinella Bacillus, Sulfurospirillum, Desulfomicrobium, Citrobacter, and Clostridium (Fan et al., 2008; Silver and Phung, 2005) while arsenite-oxidizing bacteria (or arsenite oxidizers) have been isolated from arsenic contaminated environments and classified as Pseudomonas, Thermus, Hydrogenophaga, Alcaligenes, Achromobacter, and Agrobacterium, among others (Oremland et al., 2002; Salmassi et al., 2002). In general, As(III) is more hazardous to organisms and human than As(V) (Hughes, 2002).

\section{Desorption of arsenic from bacterial biomass by acid washing}

\section{1) Effect of hydrochloric acid concentration}

Arsenic desorption resulted from bacterial biomass at different concentrations of hydrochloric acid are shown in Fig. 4. With the rise of the acid concentration to $1 \mathrm{M} \mathrm{HCl}$, arsenic in the solution increases to $3.001,2.820$, and $3.271 \mathrm{ppm}$ for WS3, WS9, and WS11, respectively. In addition, desorption of arsenic from biomass may be due to these reasons. On the biomass, the arsenic mainly adsorbs in the form of arsenic-oxygen anions with a negative charge. Firstly, chloride ions compete with arsenic-oxygen, thus releasing the adsorbed arsenic. Secondly, in the acid washing tests, with the increase of the solution acidity, desorption of arsenic has been improved due to acidolysis, making adsorbed arsenic removed from the surface of the biomass. Thirdly, hydrochloric acid makes competitive effects with arsenic-oxygen anions, which make arsenicoxygen anions formerly complexed with hydrogen of acid (Liu et al., 2014).

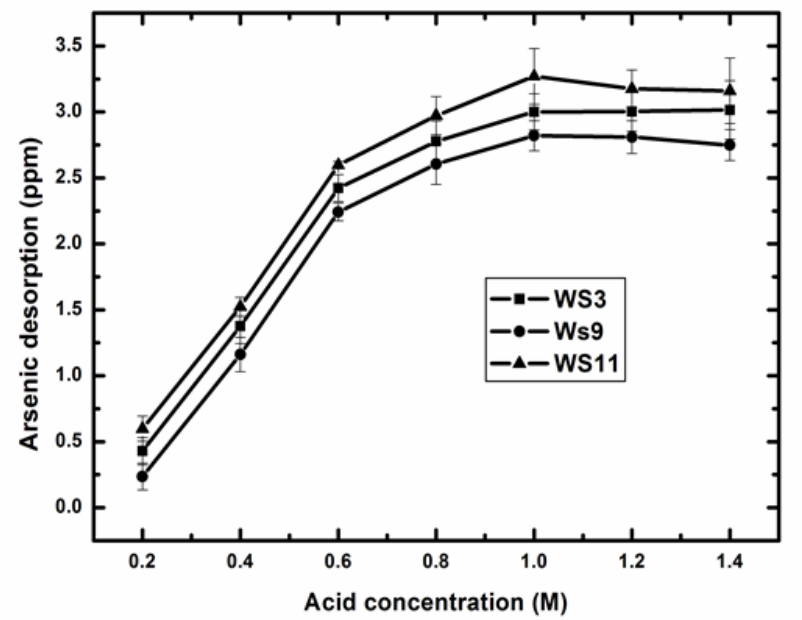

Fig. 4 Arsenic desorption from biomass using different concentrations of acid.

\section{2) Effect of contact time}

Washing time is an essential procedure factor in the bioremediation. The experiment examined the effect of time did in the optimum of acid concentration stated in the previous experiment. From Fig. 5, the rates of arsenic desorption increased rapidly within the first hour, then began to be linear, and attained maximum values of $3.241,2.998$, and $3.434 \mathrm{ppm}$ for WS3, WS9, and WS11, respectively. The desorption efficiency was enhanced significantly by increasing the washing time (Alam et al., 2001). After the acid was added to the bacterial biomass, a series of complex physical and chemical reactions occur, such as precipitation, ion exchange, and competitive adsorption (Tokunaga and Hakuta, 2002). 


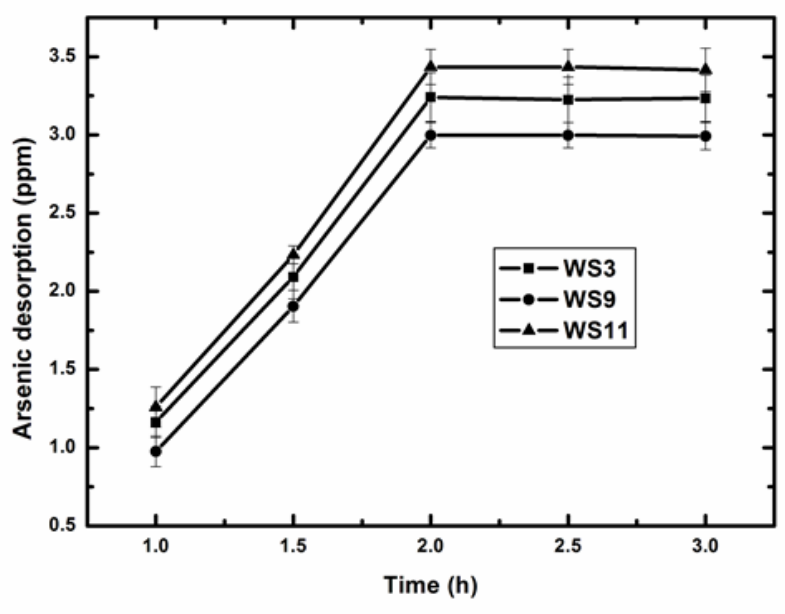

Fig. 5 Arsenic desorption of biomass at various time (h).

\section{3) Effect of bacterial biomass dosage $(\mathrm{mg})$}

The results of desorption of arsenic at different biomass dosages are shown in Fig. 6. The optimum conditions determined in the previous experiment were applied. The optimum biomass dosage was $50 \mathrm{mg}$ with arsenic desorption efficiency of 3.514, 3.299, and 3.606 ppm for all three strains WS3, WS9, and WS11, respectively. When the biomass dosage increases, the arsenic desorption also increases until certain amount after that the arsenic extracted will decrease. After $50 \mathrm{mg}$ of biomass, the arsenic desorption decreases due to the conglomeration of biomass and the acid solution does not have more contact area with biomass particles.

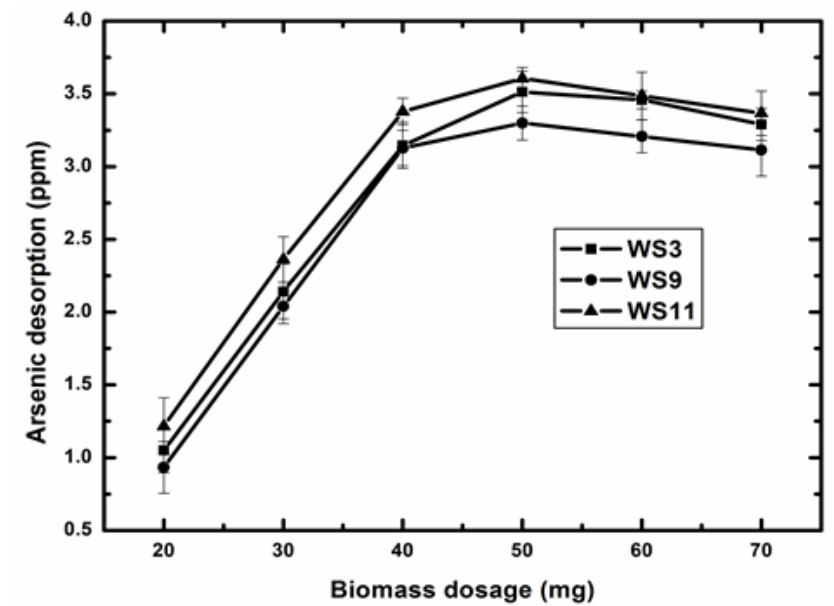

Fig. 6 Arsenic desorption of biomass using different adsorbent dosage (mg).

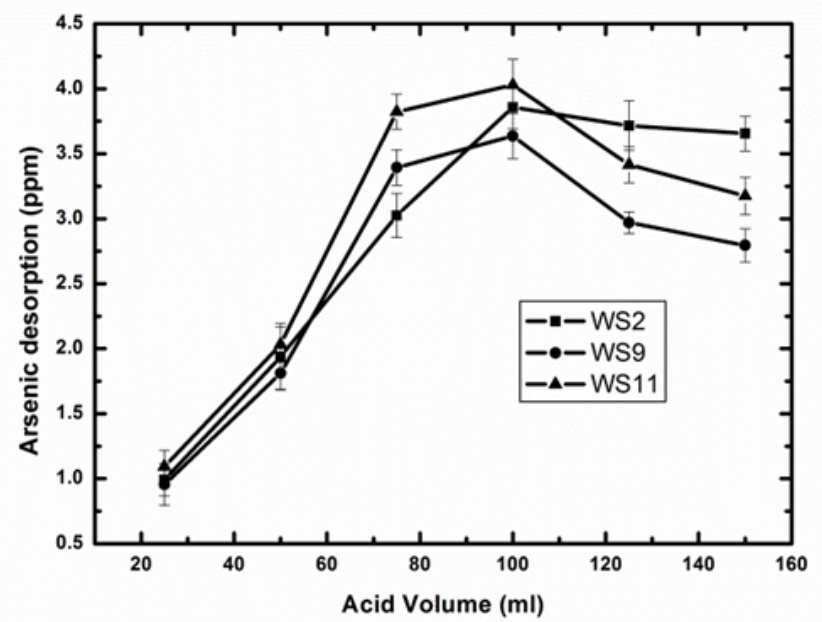

Fig. 7 Arsenic desorption of biomass using the different volume of acid (ml).

\section{4) Effect of hydrochloric acid solution volume $(\mathrm{mL})$}

The optimum concentration of acid solution volume was $100 \mathrm{ml}$ with arsenic desorbed 3.858, 3.637, and $4.030 \mathrm{ppm}$ for WS3, WS9, and WS11, respectively, as shown in Fig. 7. With the increase in acid volume, arsenic desorption increases until certain volume after which no further increase in arsenic removal is observed.

Table 1 Summary of experimental parameters for arsenic desorption from bacterial biomass and optimal values highlight in bold font.

\begin{tabular}{|c|c|c|c|c|c|c|}
\hline Experiments & $\mathbf{1}$ & $\mathbf{2}$ & $\mathbf{3}$ & $\mathbf{4}$ & $\mathbf{5}$ & $\mathbf{6}$ \\
\hline $\mathbf{H C l}$ concentration $(\mathbf{M})$ & 0.2 & 0.4 & 0.6 & $\mathbf{1}$ & 1.2 & 1.4 \\
\hline contact time (h) & 1 & 1.5 & $\mathbf{2}$ & 2.5 & 3 & - \\
\hline biomass dosage (mg) & 20 & 30 & 40 & $\mathbf{5 0}$ & 60 & 70 \\
\hline HCI Volume (mL) & 25 & 50 & 75 & $\mathbf{1 0 0}$ & 125 & 150 \\
\hline
\end{tabular}

\section{Removal of arsenite and arsenate before and after acid washing by bacterial biomass}

Although many have studied arsenic removal by bacterial biomass for water treatment purposes, only a few have explained pretreatment of biomass for the sorption reaction. Adsorption of heavy metal by microbial biomass occurs generally due to the different charges between functional groups on the microbe's surface and the heavy metals ions. Consequently, arsenic is difficult to be adsorbed by microbial biomass because, in a neutral environment, arsenite (III) is present as a neutral oxide $\left(\mathrm{H}_{3} \mathrm{AsO}_{3}\right)$ while arsenate $(\mathrm{V})$ is present as negatively charged oxide ions $\left(\mathrm{H}_{2} \mathrm{AsO}^{4-}, \mathrm{HAsO}_{4}{ }^{2-}\right)$. For the highest arsenic adsorption by bacterial biomass, the cell wall of the bacteria must be activated physically, such as in heat processing, or chemically such as in acid washing (Kapoor et al., 1999; Loukidou et al., 2003). In this study, $5 \mathrm{mg}$ of bacterial biomass of WS3, WS9, and WS11 activated by hydrochloric acid washing enhanced the arsenite removal percentage from $33 \%$ to $69 \%, 30$ to $65 \%$, and $38 \%$ to $73 \%$, respectively, as shown in Table 2 . Moreover, WS11 has the highest arsenite (III) removal (5.857 ppm) after acid washing whiles the WS9 has the lowest ability for removing arsenite (5.221 ppm) as shown in Table 2.

Table 2 Removing of As (III) (ppm) by bacterial biomass.

\begin{tabular}{|c|c|c|c|c|c|c|}
\hline \multirow{2}{*}{ 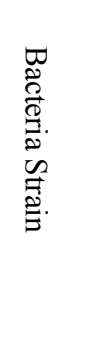 } & \multicolumn{3}{|c|}{ Before Acid washing } & \multicolumn{3}{|c|}{ After acid washing } \\
\hline & $\Omega$ & 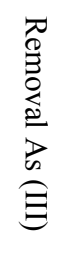 & 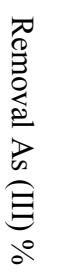 & $\Omega$ & 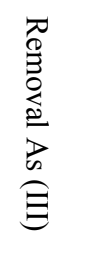 & 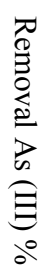 \\
\hline WS3 & 5.339 & 2.661 & 33 & 2.457 & 5.543 & 69 \\
\hline WS9 & 5.619 & 2.381 & 30 & 2.779 & 5.221 & 65 \\
\hline WS11 & 4.961 & 3.039 & 38 & 2.143 & 5.857 & 73 \\
\hline
\end{tabular}

On the other hand, the removal percentage of arsenate (V) increased from $43 \%, 42 \%, 44 \%$ to $74 \%, 70 \%, 78 \%$ after acid washing as shown in Table 3 for the three strains WS3, WS9 and WS11, respectively. Likewise, WS11 showed the highest arsenate (V) removal (5.857 ppm) after acid washing whereas WS9 was least able to remove arsenate $(\mathrm{V})(5.623 \mathrm{ppm})$ as shown in Table 3. 
Table 3 Removing of As (V)(ppm) by bacterial biomass.

\begin{tabular}{|c|c|c|c|c|c|c|}
\hline \multirow[b]{2}{*}{ 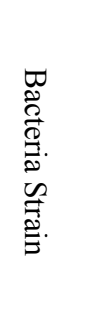 } & \multicolumn{3}{|c|}{ Before Acid washing } & \multicolumn{3}{|c|}{ After acid washing } \\
\hline & 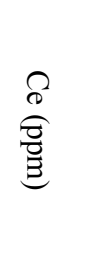 & 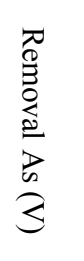 & 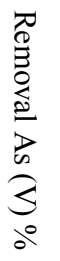 & 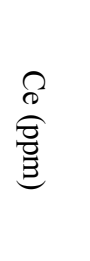 & 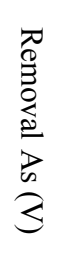 & 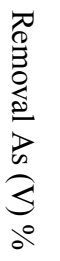 \\
\hline WS3 & 4.598 & 3.402 & 43 & 2.092 & 5.908 & 74 \\
\hline WS9 & 4.645 & 3.355 & 42 & 2.377 & 5.623 & 70 \\
\hline WS11 & 4.479 & 3.521 & 44 & 1.784 & 6.216 & 78 \\
\hline
\end{tabular}

The quantity of As (III) (mg) removed per unit of bacterial biomass $(\mathrm{g}) \mathrm{q}_{\mathrm{e}}$ was calculated using this equation (Altowayti, Allozy, et al., 2019; Haris et al., 2018):

$$
\mathrm{q}_{\mathrm{e}}=\frac{(\mathrm{Ci}-\mathrm{Ce})}{\mathrm{m}} \mathrm{V}
$$

where

$$
\begin{aligned}
& C_{e}: \text { Equilibrium concentration }(\mathrm{mg}) \\
& C_{i}: \text { Initial concentration }(\mathrm{mg}) \\
& \mathrm{m} \text { : Bacterial biomass }(\mathrm{g}) \\
& \mathrm{V}: \text { Volume of solution }(\mathrm{L})
\end{aligned}
$$

The maximal arsenite (III) loading capacity $\left(\mathrm{q}_{\mathrm{e}}\right.$ ) for the WS2, WS9, and WS11 were (11.085), (10.443) and (11.715) mg arsenite/ $\mathrm{g}$ bacteria biomass, respectively. Moreover, the ability of one unit of bacterial biomass (g) to remove a quantity of As (V) (mg) were (11.817), (11.245) and (12.431) $\mathrm{mg}$ arsenate/ $\mathrm{g}$ bacteria biomass for the WS2, WS9, and WS11, respectively.

Moreover, several researchers also reported arsenic and other heavy metal removal through various bacterial biomass and other adsorbents. For instance, two strains known as Bacillus circulans and Bacillus megaterium could remove 34.5 and $32.0 \mathrm{mg}$ of $\mathrm{Cr}(\mathrm{VI}) / \mathrm{g}$ dry weight, respectively, in $24 \mathrm{~h}$ when the initial concentration was $50 \mathrm{mg}$ $\mathrm{Cr}(\mathrm{VI}) / 1$ (Srinath et al., 2002). Similarly, a different study reported $75 \%$ of the $\mathrm{Cr}(\mathrm{VI})$ ions were removed within $30 \mathrm{~min}$ of contact and maximum removal was obtained after $8 \mathrm{~h}$ by biomass of Rhizopus nigricans (Bai and Abraham, 2001). Furthermore, the maximum adsorption capacity of hematite nanoparticles and aggregates was $(2899 \pm 71.09 \mu \mathrm{g} / \mathrm{g})$ for As (III) and $(4122 \pm 62.79 \mu \mathrm{g} / \mathrm{g})$ for As(V) at equilibrium (Dickson et al., 2017). Likewise, a different study reported $60.21 \%$ of As (III) removal through two gram biomass of shelled Moringa Oleifera seed powder (Kumari et al., 2006). In another study, Bacillus licheniformis $\mathrm{CC} 01$ and Acinetobacter calcoaceticus FN 02, released $44 \%$ to $48 \%$ of the arsenic (Clausen, 2000). Also, in a study by Miyatake and Hayashi (2009), $0.386 \mathrm{mg}$ of As (III) was removed by Bacillus megaterium strain UM-123. More recently, Miyatake and Hayashi (2011) reported $1.870 \mathrm{mg}$ of As (III) was removed by Bacillus cereus strain W2.

As a result, the arsenic adsorption capacity $\left(\mathrm{q}_{\mathrm{e}} \mathrm{mg} / \mathrm{g}\right)$ of the dried biomass of the three strains (WS3, WS9, WS11) after acid treatment was higher than that of the other adsorbents. Therefore, Pre-treatment of indigenous arsenic-resistant bacterial biomass by acid washing improves the capacity to remove As (III) and As (V) ions from aqueous solutions.

The increased removal of arsenite and arsenate by acid washing may be attributed to desorption of arsenic from the bacteria cell walls that may attach during the growth and increase the availability of the binding site. Loukidou et al. (2003) and Seki et al. (2005) identified the availability of different functional groups at different $\mathrm{pH}$ values for binding of metals. Hence, some biomass show a preference for specific heavy metals while others have broad range due to the fact that they do not exhibit any specific binding (Gupta et al., 2000). The desorption of arsenic occurred with a decrease in $\mathrm{pH}$ due to the suitable ionic state of binding ligands and metal ion species (Miyatake and Hayashi, 2009; Wu, et al., 2010). The increase in $\mathrm{pH}$ will reduce gradually the rate of protonation. Therefore, at low $\mathrm{pH}$ (acidic conditions) arsenite (III) and arsenate (V) will be expelled from the surface of biomass due to increasing rate of protonation as shown in these equations:

$$
\begin{aligned}
& \mathrm{H}_{3} \mathrm{AsO}_{3} \leftrightarrow \mathrm{HAsO}_{3}{ }^{-}+\mathrm{H}^{+} \\
& \mathrm{HAsO}_{4}{ }^{2-} \leftrightarrow \mathrm{AsO}_{4}{ }^{3-}+\mathrm{H}^{+} \\
& \mathrm{H}_{2} \mathrm{AsO}_{4}{ }^{-} \leftrightarrow \mathrm{HAsO}_{4}{ }^{2-}+\mathrm{H}^{+} \\
& \mathrm{H}_{3} \mathrm{AsO}_{4} \leftrightarrow \mathrm{H}_{2} \mathrm{AsO}_{4}{ }^{-}+\mathrm{H}^{+}
\end{aligned}
$$$$
\begin{aligned}
& \mathrm{pKa}=9.2 \\
& \mathrm{pKa}=11.5 \\
& \mathrm{pKa}=6.94 \\
& \mathrm{pKa}=2.19
\end{aligned}
$$

Desorption of other heavy metals such as cadmium and lead using acid solutions has been reported in other studies (Chang et al., 1997; Chojnacka et al., 2005; Puranik and Paknikar, 1997).

\section{CONCLUSION}

Bio-treatment is an important method for the treatment of heavy metals such as arsenic from wastewater resulting from natural or anthropogenic sources. The highest desorption of arsenic from the bacterial biomass were $3.858,3.637$, and $4.030 \mathrm{ppm}$ for WS3, WS9, and WS11, respectively, at optimum conditions. In this study, arsenicresistant bacteria WS3, WS9, and WS11 showed different affinities and capacities to remove arsenite and arsenate from aqueous solution. Moreover, the ability of WS3, WS9, and WS11 to remove arsenite and arsenate increased after acid washing plausibly due to the removal of adsorbed arsenic from the cell wall. Consequently, acid washing of bacterial biomass as a pre-treatment step is highly recommended prior to arsenic removal from wastewater. Biomass regeneration is also important for the practical applicability of the biomass when wastewater treatment is considered.

\section{ACKNOWLEDGEMENT}

The authors thank the Ministry of Education Malaysia and Universiti Teknologi Malaysia for funding project FRGS Grant No 4F184 and RUG Grant 11H94. Wahid Ali Hamood Altowayti extends his gratitude to the Ministry of Higher Education of Yemen for the scholarship.

\section{REFERENCES}

Alam, M., Tokunaga, S. and Maekawa, T. (2001). Extraction of arsenic in a synthetic arsenic-contaminated soil using phosphate. Chemosphere, 43(8), 1035-1041.

Altowayti, W. A. H., Algaifi, H. A., Bakar, S. A. and Shahir, S. (2019). The adsorptive removal of As (III) using biomass of arsenic resistant Bacillus thuringiensis strain WS3: Characteristics and modelling studies. Ecotoxicology and Environmental Safety, 172, 176-185.

Altowayti, W. A. H., Allozy, H. G. A., Shahir, S., Goh, P. S. and Yunus, M. A. M. (2019). A novel nanocomposite of aminated silica nanotube (MWCNT/Si/NH 2) and its potential on adsorption of nitrite. Environmental Science and Pollution Research, 1-12.

Anderson, C. R. and Cook, G. M. (2004). Isolation and characterization of arsenate-reducing bacteria from arsenic-contaminated sites in New Zealand. Current microbiology, 48(5), 341-347.

Bahari, Z. M., Altowayti, W. A. H., Ibrahim, Z., Jaafar, J. and Shahir, S. (2013). Biosorption of As (III) by non-living biomass of an arsenichypertolerant Bacillus cereus strain SZ2 isolated from a gold mining environment: Equilibrium and kinetic study. Applied Biochemistry and Biotechnology, 171(8), 2247-2261.

Bai, S. and Abraham, T. E. (2001). Biosorption of Cr (VI) from aqueous solution by Rhizopus nigricans. Bioresource Technology, 79(1), 73-81.

Chang, J.-S., Law, R. and Chang, C.-C. (1997). Biosorption of lead, copper and cadmium by biomass of Pseudomonas aeruginosa PU21. Water Research, 31(7), 1651-1658.

Chiancone, E. and Ceci, P. (2010). The multifaceted capacity of Dps proteins to combat bacterial stress conditions: detoxification of iron and hydrogen peroxide and DNA binding. Biochimica et Biophysica Acta (BBA)General Subjects, 1800(8), 798-805.

Chojnacka, K., Chojnacki, A. and Gorecka, H. (2005). Biosorption of Cr3+, $\mathrm{Cd} 2+$ and $\mathrm{Cu} 2+$ ions by blue-green algae Spirulina sp.: Kinetics, 
equilibrium and the mechanism of the process. Chemosphere, 59(1), 7584.

Clausen, C. A. (2000). Isolating metal-tolerant bacteria capable of removing copper, chromium, and arsenic from treated wood. Waste Management and Research, 18(3), 264-268.

Cummings, D. E., Caccavo Jr, F., Fendorf, S. and Rosenzweig, R. F. (1999). Arsenic mobilization by the dissimilatory Fe (III)-reducing bacterium Shewanella alga BrY. Environmental Science \& Technology, 33(5), 723729.

Dickson, D., Liu, G. and Cai, Y. (2017). Adsorption kinetics and isotherms of arsenite and arsenate on hematite nanoparticles and aggregates. Journal of Environmental Management, 186, 261-267.

Escalante, G., Campos, V., Valenzuela, C., Yañez, J., Zaror, C. and Mondaca, M. (2009). Arsenic resistant bacteria isolated from arsenic contaminated river in the Atacama Desert (Chile). Bulletin of Environmental Contamination and Toxicology, 83(5), 657-661.

Fan, H., Su, C., Wang, Y., Yao, J., Zhao, K., Wang, Y., et al. (2008). Sedimentary arsenite-oxidizing and arsenate-reducing bacteria associated with high arsenic groundwater from Shanyin, Northwestern China. Journal of Applied Microbiology, 105(2), 529-539.

Gupta, R., Ahuja, P., Khan, S., Saxena, R. and Mohapatra, H. (2000). Microbial biosorbents: meeting challenges of heavy metal pollution in aqueous solutions. Current Science Bangalore, 78(8), 967-973.

Haris, S. A., Altowayti, W. A. H., Ibrahim, Z. and Shahir, S. (2018). Arsenic biosorption using pretreated biomass of psychrotolerant Yersinia sp. strain SOM-12D3 isolated from Svalbard, Arctic. Environmental Science and Pollution Research, 25(28), 27959-27970.

Hughes, M. F. (2002). Arsenic toxicity and potential mechanisms of action. Toxicology letters, 133(1), 1-16.

Kapoor, A., Viraraghavan, T. and Cullimore, D. R. (1999). Removal of heavy metals using the fungus Aspergillus niger. Bioresource Technology, 70(1), 95-104.

Kumari, P., Sharma, P., Srivastava, S. and Srivastava, M. (2006). Biosorption studies on shelled Moringa oleifera Lamarck seed powder: removal and recovery of arsenic from aqueous system. International Journal of Mineral Processing, 78(3), 131-139.

Liu, P. Y., Liu, H., Li, Y. J. and Dong, C. X. (2014). Remediation of arsenic contaminated soils and treatment of washing effluent using calcined MnFe Layered double hydroxide. Proceedings of the 2014 Advanced Materials Research,

Loukidou, M. X., Matis, K. A., Zouboulis, A. I. and Liakopoulou-Kyriakidou, M. (2003). Removal of As (V) from wastewaters by chemically modified fungal biomass. Water Research, 37(18), 4544-4552.

Martinez, A. and Kolter, R. (1997). Protection of DNA during oxidative stress by the nonspecific DNA-binding protein Dps. Journal of Bacteriology, 179(16), 5188-5194

Miyatake, M. and Hayashi, S. (2009). Characteristics of arsenic removal from aqueous solution by Bacillus megaterium strain UM-123. Journal of Environment and Biotechnology, 9(2), 123-129.

Miyatake, M. and Hayashi, S. (2011). Characteristics of arsenic removal by Bacillus cereus strain W2. 環境資源工学, 58(3), 101-107.
Mohan, D. and Pittman, C. U. (2007). Arsenic removal from water/wastewater using adsorbents - a critical review. Journal of Hazardous Materials, 142(1), 1-53.

Oremland, R. S., Hoeft, S. E., Santini, J. M., Bano, N., Hollibaugh, R. A. and Hollibaugh, J. T. (2002). Anaerobic oxidation of arsenite in Mono Lake water and by a facultative, arsenite-oxidizing chemoautotroph, strain MLHE-1. Applied and Environmental Microbiology, 68(10), 4795-4802.

Pepi, M., Volterrani, M., Renzi, M., Marvasi, M., Gasperini, S., Franchi, E., et al. (2007). Arsenic-resistant bacteria isolated from contaminated sediments of the Orbetello Lagoon, Italy, and their characterization. Journal of Applied Microbiology, 103(6), 2299-2308.

Puranik, P. and Paknikar, K. (1997). Biosorption of lead and zinc from solutions using Streptoverticillium cinnamoneum waste biomass. Journal of Biotechnology, 55(2), 113-124.

Salmassi, T. M., Venkateswaren, K., Satomi, M., Newman, D. K. and Hering, J. G. (2002). Oxidation of arsenite by Agrobacterium albertimagni, AOL15, sp. nov., isolated from Hot Creek, California. Geomicrobiology Journal, 19(1), 53-66.

Seki, H., Suzuki, A. and Maruyama, H. (2005). Biosorption of chromium (VI) and arsenic (V) onto methylated yeast biomass. Journal of Colloid and Interface Science, 281(2), 261-266.

Silver, S. and Phung, L. T. (2005). Genes and enzymes involved in bacterial oxidation and reduction of inorganic arsenic. Applied and Environmental Microbiology, 71(2), 599-608.

Simeonova, D. D., Lievremont, D., Lagarde, F., Muller, D. A., Groudeva, V. I. and Lett, M.-C. (2004). Microplate screening assay for the detection of arsenite-oxidizing and arsenate-reducing bacteria. FEMS Microbiology Letters, 237(2), 249-253.

Singh, N., Kumar, D. and Sahu, A. P. (2007). Arsenic in the environment: effects on human health and possible prevention. Journal of Environmental Biology, 28(2), 359.

Srinath, T., Verma, T., Ramteke, P. and Garg, S. (2002). Chromium (VI) biosorption and bioaccumulation by chromate resistant bacteria. Chemosphere, 48(4), 427-435.

Suresh, K., Prabagaran, S., Sengupta, S. and Shivaji, S. (2004). Bacillus indicus sp. nov., an arsenic-resistant bacterium isolated from an aquifer in West Bengal, India. International Journal of Systematic and Evolutionary Microbiology, 54(4), 1369-1375.

Tokunaga, S. and Hakuta, T. (2002). Acid washing and stabilization of an artificial arsenic-contaminated soil. Chemosphere, 46(1), 31-38.

Valls, M. and De Lorenzo, V. (2002). Exploiting the genetic and biochemical capacities of bacteria for the remediation of heavy metal pollution. FEMS Microbiology Reviews, 26(4), 327-338.

Wu, Y. H., Feng, S. X., Li, B. and Mi, X. M. (2010). The characteristics of Escherichia coli adsorption of arsenic (III) from aqueous solution. World Journal of Microbiology and Biotechnology, 26(2), 249-256.

Zaini, H., Mohd, N. A. R., Siti, M. S., Yamin, Y. and Ahmad, S. (2011). Removal of copper from aqueous solution by adsorption using magnesium aluminium hydrogen phosphate layered double hydroxides. Journal of Nuclear and Related Technologies, 8(2), 60-67. 